\title{
Teaching Statistical Methods FOR MANAGEMENT: STATISTICAL THINKING APPROACH
}

\author{
SIMICEVIC, V.
}

Abstract: This paper emphasizes the importance of statistical approach to intelligent managerial decision-making. The research was based on an original empirical survey, conducted on the basis of a random sample of large Croatian firms, aimed at estimating the extent at which Croatian managers use statistical methods. The research results are presented in this paper, and suggestions are given for the promotion of the statistical education in order to increase the level of statistical thinking in Croatian firms.

Key words: statistical education, statistical thinking, intelligent methods, managerial decision making
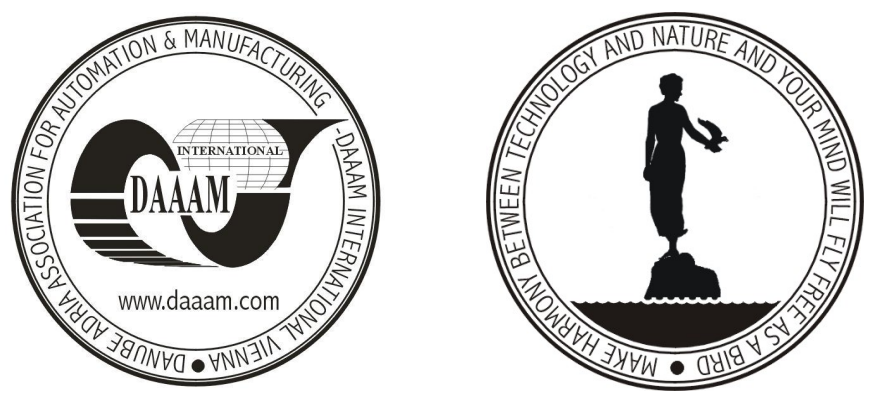

Authors' data: $\mathrm{PhD}$. Simicevic, V[anja], Center for Croatian Studies, University of Zagreb, Picmanova 2, Zagreb 10 010, Croatia, vanja.simicevic@zg.htnet.hr

This Publication has to be referred as: Simicevic, V. (2007). Teaching Statistical Methods for Management: Statistical Thinking Approach, Chapter 47 in DAAAM International Scientific Book 2007, B. Katalinic (Ed.), Published by DAAAM International, ISBN 3-901509-60-7, ISSN 1726-9687, Vienna, Austria DOI: $10.2507 /$ daaam.scibook.2007.47 